\title{
Makerspace as Emerging Technology and Innovation in Academic Libraries: A Call for Adoption in Abubakar Tafawa University Library Bauchi
}

\author{
Suleiman Abdullahi, Mnla, cln. \\ Abdullahi A. Dewa \\ Abubakar Tatari Ali Polytechnic Library Bauchi, Nigeria.
}

\author{
Hassan Adamu \\ Muhammadu Wabi Libraray Federal Polytechnic Bauchi
}

\begin{abstract}
This study was conducted to examine makerspace as emerging technology and innovation in academic libraries: a call for adoption in ATBU library, Bauchi. Bauchi state, Nigeria. The population of the study comprised of 26 ATBU academic librarians.Survey research method was adopted for the study. Questionnaire was used as a data collection instrument. Frequency counts and simple percentages were used in analysing the data collected. The study revealed that academic librarians of $A T B U$ are unaware of makerspace as a new emerging technology and as such a call for its adoption is paramount. Highlight of some benefits for adoption of makerspace in libraries were made which includes, Increased motivation of academic librarians and students, enhanced learning activity among academic librarians and users, and create interdisciplinary teamwork among the academic librarians and library users. The study recommended among others, Academic librarians should embrace the new emerging technology and participate fully through training on the new technology and bring about the development of Makerspace in their libraries. This will also go a long way in creating and sharing of new ideas among themselves.
\end{abstract}

Keywords:- Makerspace, Technology, Innovation, Academic Libraries.

\section{INTRODUCTION}

The world is changing and libraries too, and as Moorefield-Lang (2015) stated, library services need to evolve with this change. The major role of universities and other tertiary institutions revolves round the development of the society through research, teaching and community service. An academic library is an integral part of a college, university or other tertiary institutions, administered to meet the information and research needs of its students, faculty and staff (Reitz, 2004). In line with this statement, Oduagwu (2006) described academic libraries as libraries in institutions of higher learning, which are devoted to the academic activities of their parent's institutions. Furthermore, academic libraries ensure the provide service to academic community. Academic libraries by their nature and functions ensure the development of intellectual consciousness and potentials of members of academia on

\author{
Ibrahim Usman \\ Muhammadu Wabi Libraray Federal Polytechnic Bauchi
}

one hand and the larger society on the other hand. As the $21^{\text {st }}$ century progresses, tertiary education is becoming more dynamic and technology driven and academic libraries are not left out. Automation and remote use caused a drawback for academic libraries in the past few years. In addition, universities and academic libraries are seen to be maximizing the use of space to support both the libraries' activities and mandate of its parent body, sometimes in competition with other stakeholders in the institution. However, Physical visits to the library are decreasing, costing the library its patrons, and perhaps its survival. In this competitive world, academic libraries are competing to attract patrons to use their services. This competing world is leading to a special focus on the patron as a customer that need to be satisfied. New services are emerging, and innovative means of offering online information resources are being created. All of these efforts are to Maker-space: According to Fatima, A.M AlMousawi (2017), all these new trends in library operations is to ensure the survival, and sustainability of the academic library.

An emerging innovation and development in academic libraries was introduced in America and Australia. This new technology according to Turner, Welch and Reynolds (2013), is known as makerspace. The new trends have appeared, focusing on the promotion of physical visits to the library, attracting the users, and promoting the library as an active place. According to Hussain and Nisha (2017), maker-space is physical space in the library founded to allow information, knowledge, and experience sharing, and it hosting different people that have different backgrounds academically, and socially. This space is enabling its users to perform variety of activities, weather if they were technical, or theoretical. A maker space is a location where students and patrons can create, craft, solve problems, and develop new skills (Preddy, 2013). They are also a location where users can learn through experimentation and play. Maker spaces are places where library clients can come together to share, collaborate, and explore (Britton, 2012). No one maker space is the same. Some of these learning spaces are focussed on technology where programming, hacking, music recording, and design are the norm. Other maker spaces are dedicated to crafting and arts where patrons will knit, sew, paint, and create ingenious items from weeded 
books. Also, Hussain and Nisha (2017) stated that makerspaces has different names, and those names referred to what activity they are holding, for example, maker-space that is involving in computer interests, technology, and science is called hacker-space. Adrezin and Wilczynski (2016) mentioned that the start of the concept of makerspaces was in 1998 in MIT class, under the name of fab-lab (fabrication lab). As Halverson, and Sheridan (2014) stated, today, the fab lab foundation is supporting the creation of any fab lab all over the world, which shows an international support. Thereafter, Books, and research papers started to evolve around this concept to study its effect, benefits, expenses, and what competencies needed for the professional librarians who supervise such spaces.

\section{$>$ Statement of the Problem}

Many academic libraries in America and Australia have begun providing access to maker resources and services (Radniecki and Klenke, 2017). Maker-spaces are not popular, or well known in academic libraries in Nigeria. It is not certain whether academic libraries are willing to embrace this emerging technology. It is in line with this aspect, that this research paper seeks to investigate makerspace as emerging technology and innovation in academic libraries with a view to pursuean academic library maker space so as to be part of the global world technological trend in ATBU library Bauchi.

\section{$>$ Objectives of the Study}

The general purpose of this paper is to identify makerspace as an emerging technology and innovation and to call for its adoption particularly in ATBU library Bauchi. The Specific objectives are:

- To identify makerspace as emerging technology in academic libraries

- To determine the need for adoption of makerspace in ATBU Library

- To examine the benefits of adoption of makerspace in ATBU Library

- To find out the possible challenges of adopting makerspace in ATBU Library

- To proffer solutions to effective adoption of makerspace in ATBU Library

\section{$>$ Research Questions}

- How is Makerspace considered to be an emerging technology in academic Libraries?

- Why do we need to adopt makerspace in ATBU Library?

- What are the benefits of adopting maker space in ATBU Library?

- What are the challenges to be encountered in adopting makerspace in ATBU Library?

- What solutions to provide for effective adoption of makerspace in ATBU Library?

\section{LITERATURE REVIEW}

\section{$>$ The concept of maker Space as emerging technology and innovation I academic libraries}

In the past, there has been tremendous interest in makerspace and their potential in libraries from school libraries and public libraries to academic libraries and to special libraries. The topic seems very much the flavor of the moment particularly, academic libraries. Makerspaces and varying new technologies are exciting services being offered in libraries particularly academic libraries. This initiative speaks not only the reconfiguration of available space but also the training of library staff to work collaboratively with faculty and information technology sector of the university in sustaining this endeavor. It is therefore, essential that models of makerspaces are carefully examined before implementation (MoorefieldLang, H., 2015, Wong and Partridge, 2016).

Makerspaces are a growing service area for many libraries in school, public, and academic settings. Participants, or makers, can create digital and physical items in common working spaces using shared equipment and resources. The essential makerspace elements of makers, tools, space, and shared expertise are also often joined by a spirit of individual exploration and discovery through creative activities. One area of balance in makerspaces is in providing group training on specific creative activities while also offering open lab times in the makerspace for individuals to work independently or in small collaborative groups on their projects. This is particularly acute in the academic environment, where lab spaces (whether for computers, biology, chemistry, engineering, or nursing) are often imagined for use by classes of students working on an assignment or project. Can an open, self-directed approach work in an environment where much learning is encapsulated in semester-long courses and student learning is assessed by assignments with relatively rigid timelines and criteria? The alternative, maker-focused mindset would allow for tinkering and play to be utilized by makers as they create and learn. Burk, John (2017).

Makerspace encompasses a continuum of activity that include "co-working" "hacker space" and "fab lab", the common thread running through each is a focus on making rather than merely consuming. Makerspaces can be a mechanism for encouraging students to experiment and learn beyond the classroom and outside of the normal structure of their assignments. Students are encouraged to examine new means of creation and in doing so they strengthen and apply more broadly the learning they experience in their courses. According to John Burk (2015), a maker space is an area in a library where users can use tools and equipments to design, build and create all sorts of different things. It may be a dedicated room or a multipurpose space in which a collection of raw materials and resources can be utilized as desired. Projects range from prototyping product designs with 3D printers, to programming robots, to creating art out of recycled items. Wikipedia further described maker space as a community- 
operated workspace where people with common interests, often in computers, machining, technology, science, digital art or electronic art, can meet, socialized and collaborate. This means people of the same interest can meet or collaborate together for the purpose of achieving a set goal. Additionally, a maker space can be an area traditionally found in public libraries that offers patrons an opportunity to create content through various resources such as computers, 3D printers, audio and visual devices and traditional arts and craft materials, including ecologic materials. However, in the field of library science, maker space are classified as a type of library services offered by librarians to patrons.

The Birth of maker spaces can be traced to the maker movement outside the university system at the turn of the century as the next iteration of the Do-It-Yourself (DIY) culture (Anderson,2012).Also, Britton (2012) posits that maker spaces started emerging in the form of open spaces where members would pay membership fees for access to the technology. Burk (2014) stated that makerspace existed in various forms as long as people have been making items and have needed places to work with tools and equipments. He also stated that the launch of "Make" magazine and other related information on the project have given the new technology a greater impetus.

University makerspaces are places where students and staff can learn new things, work with their peers, consider new ideas, explore, tinker, invent and make. According to Matthews, G., \& Walton, G. (2017), stated that the future of libraries is about a user community engaging to create content and using it for community building connecting people, engaging students, assisting researchers and advancing knowledge production.

\section{$>$ The need for adoption of maker space in academic libraries}

Since the world is embracing new technology, academic libraries should not be left out in being part of the emerging trend. Therefore, academic libraries are encouraged to adopt the new innovation for prosperity and for the advancement of their libraries. Recent trends in librarianship points to the themes of crafting, artisans, creators and makers in library spaces. One of the trends is the maker movement, which the artisans, creators and makers find ways in which libraries can support these movement and entrepreneurship (Filar Williams and Folkham, 2017). Hynes and Hynes (2014) studied the appearance of maker-spaces, and its suitable physical design. The authors surveyed students about the image of the maker-spaces. The focus was on complexity, coherence, mystery, and legibility average of the physical design. The results provided initial insights into how students perception can form a preferred environment in order to help guide the physical design of maker-spaces.Taylor, Hurly, and Connolly (2016) believed that an individual who have the right set of skills will be able to produce better, and cheaper solutions, compared with mass production figures, and this may be accomplished in maker-spaces. On another hand, Quinn (2000). stated that in this world of competition, academic libraries have to offer more, be unique, and treat the students as customers. In order to attract customers, new services, and appealing entities have to be emerged, and established. A maker space can present this new service that can attract patrons back to the library, and serving their goals too, whether they were educational, or cultural. The study also can add to the body of knowledge of the profession.

The library has space and material for learning about all academic disciplines. More importantly, the availability of materials spanning wide arrays of subject matter encourages constructing knowledge across and outside of disciplines. Makerspaces provide access to physical resources typically regarded as materials for crafting, engineering, design, robotics, or media. They encourage blending these specialties in the service of learning any academic or traditionally non-academic disciplines. This access to physical materials which leads to blending of services encouraged the need for adoption of the new technology in academic libraries specifically ATBU library Bauchi.

Libraries provide access to many print, visual, and virtual information resources that would not be accessible to most students and faculty, even in today's highly connected world. Makerspaces provide access to tools and materials that would be too expensive or impractical for most students or teachers to have as individuals or in a classroom. If ATBU library can make available, tools and other resources for making materials to students and other users for certain fee, it will serve as a way of generating revenue as well as a place for learning new technology.

Ginsberg (2016) in a study on why makerspace matter in academic libraries, posits that most of the community makerspaces exist in public libraries, university makerspace in academic libraries have been on the increase and for good reasons, being that as academic libraries exist to encourage and support campus scholarship, makerspace exist to encourage creative learning, using available spaces and can easily co-exist in the library. There are many reasons why the need for adoption of makerspace in libraries; some of these reasons are as given below:

\section{- It enables libraries teaches creative literacy:}

This means libraries teaches information literacy to its users so as to availed them with current trends on information resources. Makerspaces are changing the way students learn today and potentially how they live and work in the future (Harmony Hilmaz, 2017). Introducing makerspace in ATBU library will enable students and staff of the university community to benefit a lot by learning how to think entrepreneurially and develop skills that are going to be invaluable. It's like training today for jobs that don't exist yet. Therefore, makerspaces encourage students to innovate and build critical thinking. 
- Libraries and makerspaces are inherently interdisciplinary spaces.

The library has space and material for learning about all academic disciplines. More importantly, the availability of materials spanning wide arrays of subject matter encourages constructing knowledge across and outside of disciplines. Makerspaces provide access to physical resources typically regarded as materials for crafting, engineering, design, robotics, or media. They encourage blending these specialties in the service of learning any academic or traditionally non-academic disciplines.

\section{- Libraries and makerspaces provide equitable access to} materials and resources.

Libraries provide access many print, visual, and virtual information resources that would not be accessible to most students and faculty, even in today's highly connected world. Makerspaces provide access to tools and materials that would be too expensive or impractical for most students or teachers to have as individuals or in a classroom.

- Makerspaces and libraries are more than just resource closets.

Librarians and makerspace facilitators are themselves resources, providing structured programming such as workshops and classes, as well as customized one-on-one or full-class guidance, mentoring, and much more. Ondemand access to material and human resources helps students learn in powerful ways, unconstrained by limitations of time, space, and topics of inquiry.

\section{- Libraries and makerspaces serve the common goal of} building community.

Communities of interest and practice are brought together and maintained through the design of communal space to promote sociality and collaboration (while also providing spaces for individual work). Other programming, like workshops, book groups, and clubs, are encouraged to take place or to form in these spaces. These communities serve as an audience of users and viewers for the artifacts of knowledge being created in both spaces, and can help to share these artifacts even more widely. Therefore, makerspace provides an opportunity for libraries to build upon services they already offer while reaching out to students and faculty who do not frequent the library on daily basis.

\section{$>$ Benefits for adoption of maker space in ATBU library}

As maker space continue to be adopted by academic libraries and many organizations all over the world, many benefits can be derived from their establishment as identified by Weinmann (2014), that such benefits to be derivable from adoption of makerspace by academic library includes: increased motivation of students, enhanced learning and more possibilities for interdisciplinary team work and the development of an entrepreneurial spirit. These points were also supported by the American Society for Engineering Education (ASEE) (2015) which stated that the benefits of makerspaces are primarily focused around two major concepts; the benefits of building physical models and the benefits of informal learning environments and community. Slater and Howard (2013), also posits that while the focus is often on technology, makerspaces concentrates more on creation. Therefore, if makerspace is adopted in ATBU library, students, researchers and community staff will benefit a lot by learning new innovations and the library will be listed as among those that adopted the new technology in the country.Makerspace can be a reason for the students to increase their visits to the library, which will make the library more valuable place, affecting its survival positively. Findings of the study can be used as a proof to participate in the decision of emerging maker-spaces in academic libraries of Nigerian universities (Fatma A M AL-Mousawi,2018).

\section{RESEARCH METHODOLOGY}

\section{$>$ Methodology}

A descriptive survey research design was adopted for this study. Questionnaire was prepared to collect data from librarians of ATBU library and to address the 5 research questions. Mean and Standard Deviation of the five research questions of the study based on the responses of the respondents against the items on the questionnaire while the responses recorded from the interview were analyzed qualitatively and supported the responses elicited from the questionnaire and presented after each quantitative data. The population of the study comprised of 26 ATBU academic librarians. A total of 150 questionnaires were distributed among the academic librarians of the university. Out of 150 questionnaires distributed, 130 valid questionnaires were collected. Data was analyzed, using SPSS specifically to determine percentages and mean.

\section{Result and Discussion}

Data were analyzed and results were presented in line with the study research questions.

\section{- Research Question 1}

Are you aware that Makerspace is an emerging technology and innovation in libraries?

\begin{tabular}{|c|c|c|c|}
\hline Level of awareness & Aware F(\%) & Not Aware F(\%) & Total \\
\hline Academic Librarians & $6(23.1)$ & $20(76.9)$ & $26(100)$ \\
\hline Total & $\mathbf{6}$ & $\mathbf{2 0}$ & $\mathbf{2 6}$ \\
& $\mathbf{2 3 . 1 \%}$ & $\mathbf{7 6 . 9 \%}$ & $(\mathbf{1 0 0 \%})$ \\
\hline
\end{tabular}

Table 1:- Awareness of makerspace as an emerging technology and innovation in academic libraries

Table 1 above, shows that 6(23.1\%) of the respondents are aware of the emerging new technology while 20(76.9\%) are unaware of the new concept in academic libraries. 
- Research Question 2

Why do we need to adopt Makerspace in ATBU libarary?

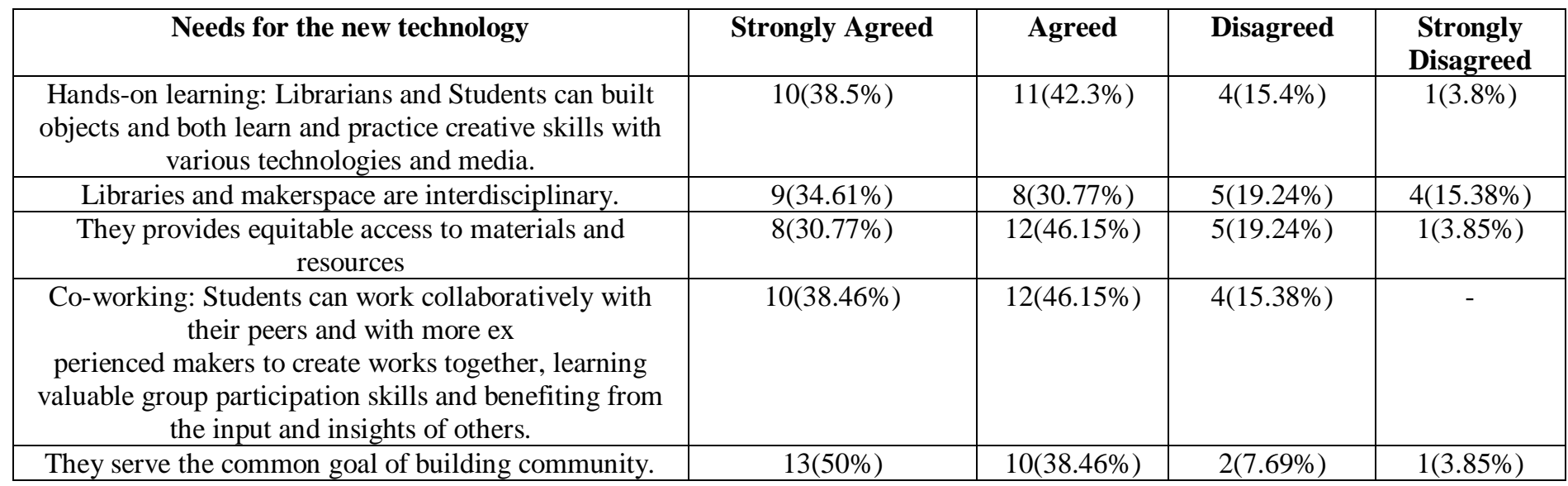

Table 2:- Need for adoption of maker space in ATBU library

Table 2 above revealed that $10(38.46 \%)$ of the respondents strongly agreed that the need to adopt Makerspace will enable libraries teach creative literacy and : Students can work collaboratively with their peers and with more ex perienced makers to create works together, learning valuable group participation skills and benefiting from the input and insights of others. However, $12(46.15 \%)$ and $11(42.3 \%)$ agreed for adoption of new technology while 5(19.24 and 4(15.38\%) disagreed and 1(3.85\%) indicated their disagreement to the new technology.

- Research Question 3

What are the benefits for adoption of maker space in ATBU library?

\begin{tabular}{|c|c|c|c|c|}
\hline Benefits & $\begin{array}{l}\text { Strongly } \\
\text { Agreed }\end{array}$ & Agreed & Disagreed & $\begin{array}{c}\text { Strongly } \\
\text { Disagreed }\end{array}$ \\
\hline Enhanced learning activity among students. & $15(57.69 \%)$ & $9(34.61 \%)$ & $1(3.85 \%)$ & $1(3.85 \%)$ \\
\hline $\begin{array}{l}\text { They enable individuals to collaborate on projects and bring } \\
\text { multiple perspectives and skill sets together. }\end{array}$ & $10(38.46 \%)$ & $13(50 \%)$ & $3(11.54 \%)$ & - \\
\hline
\end{tabular}

Table 3:- Benefits for adoption of makerspace in ATBU Library

Table 3 above indicates the benefits for adoption of Maker space in ATBU library. Findings revealed that 14(53.85\%) and $16(61.54 \%)$ of the respondents strongly agreed that adoption of makerspace in the library would increase motivation of academic librarians and students and it will also develop an entrepreneurial spirit among users. However, 13(50\%) and 10(38.46\%) agreed that it would enable individuals to collaborate on projects and bring multiple perspectives and skill sets together and Increased motivation of academic librarians and student while 3(11.54\%) and 2(7.69\%) disagreed. Other respondents strongly indicate their disagreement to the benefits of the emerging trends $1(3.85 \%)$.

\section{- Research Question 4}

What are the possible challenges to encounter for adoption of maker space in ATBU library?

\begin{tabular}{|c|c|c|c|c|}
\hline Challenges & $\begin{array}{l}\text { Strongly } \\
\text { Agreed }\end{array}$ & Agreed & Disagreed & $\begin{array}{l}\text { Strongly } \\
\text { Disagreed }\end{array}$ \\
\hline $\begin{array}{l}\text { Staffing can be an issue as well } \\
\text { because no one person has the full time job of running the } \\
\text { teen center, so it is shared among many. }\end{array}$ & $12(46.15 \%)$ & $10(38.46 \%)$ & $3(11.54 \%)$ & $1(3.85 \%)$ \\
\hline $\begin{array}{l}\text { Inadequate Funding. } \\
\end{array}$ & $14(53.85 \%)$ & $10(38.46 \%)$ & $2(7.69 \%)$ & - \\
\hline Lack of proper maintenance of the equipments. & $13(50 \%)$ & $9(34.62 \%)$ & $2(7.69 \%)$ & $2(7.69 \%)$ \\
\hline Inadequate space to dedicate to makerspace. & $10(38.46 \%)$ & $12(46.15 \%)$ & $3(11.54 \%)$ & $1(3.85 \%)$ \\
\hline $\begin{array}{l}\text { Problem of Noisiness that would arise from the use of } \\
\text { equipments. }\end{array}$ & $12(46.15 \%)$ & $10(38.46 \%)$ & $1(3.85 \%)$ & $3(11.54 \%)$ \\
\hline
\end{tabular}

Table 4:- Possible challenges to encounter for adoption of makerspace in ATBU Library 
Table 4 above, revealed the possible challenges to encounter for the adoption of maker space in ATBU Library. Findings revealed that some of the challenges to encounter are issue of staffing 12(46.15\%); Inadequate funding 14(53.85\%); and problem of noisiness to be encountered in the library 12(46.15). Also, 10(38.46\%) agreed to the challenges while $1(3.85 \%)$ strongly disagreed. The Researcher observed that the most challenging factors for establishing a makerspace in ATBU library are: problem of inadequate funding, lack of maintenance of the equipments, and shortage of staff. The Study however, recommended among others; adequate funding of the library, employment of more staff in the library to ensure adequate maintenance of the equipments and dedicate a separate space far from the reading area to avoid disturbance of other library users.

- Research Question 5:

What are Solutions to effective adoption of maker space in ATBU Library?

\begin{tabular}{|c|c|c|c|c|}
\hline Solutions & Strongly Agreed & Agreed & Disagreed & $\begin{array}{c}\text { Strongly } \\
\text { Disagreed }\end{array}$ \\
\hline Provision of adequate funding of the project. & $14(53.85 \%)$ & $11(42.3 \%)$ & $1(3.85 \%)$ & - \\
\hline $\begin{array}{l}\text { Provision of enough space for the new technology in } \\
\text { the library. }\end{array}$ & $10(38.46 \%)$ & $15(57.69 \%)$ & $1(3.85 \%)$ & - \\
\hline $\begin{array}{c}\text { Training of academic librarians on Makerspace } \\
\text { technology }\end{array}$ & $11(42.3 \%)$ & $13(50 \%)$ & $1(3.85 \%)$ & $1(3.85 \%)$ \\
\hline Ensure adequate security measures. & $15(57.69 \%)$ & $10(38.46 \%)$ & $1(3.85 \%)$ & - \\
\hline Adequate provision of power supply in the library. & $10(38.46 \%)$ & $14(53.85 \%)$ & $1(3.85 \%)$ & $1(3.85 \%)$ \\
\hline $\begin{array}{l}\text { Ensure proper awareness on the new technology to the } \\
\text { academic librarians and other users. }\end{array}$ & $13(50 \%)$ & $10(38.46 \%)$ & $2(7.69)$ & $1(3.85 \% 0$ \\
\hline
\end{tabular}

Table 5:- Solutions to effective adoption of makerspace in ATBU Library

Table five above, indicated the respondents agreement to the solutions on the effective adoption of makerspace in academic libraries. Findings revealed that 15(57.69\%), $14(53.85 \%)$, and $13(50 \%)$ has the highest respondents that strongly agreed to the solutions provided. Also, $15(57.69 \%), 14(53.85 \%)$ and $13(50 \%)$ agreed while $2(7.69 \%)$ and $1(3.85 \%)$ disagreed and strongly disagreed on various solutions provided. The Study discovered that most of the respondents strongly agreed to the solutions provided while others agreed to the solutions. Other respondents that indicated their disagreement may due to their level of understanding the importance of the new technology in their libraries.

\section{DISCUSSIONS AND FINDINGS}

From the data obtained and presented in line with research question 1 , as presented in table 1, 20(76.9\%) of academic librarians are not aware of the new emerging technology while $6(23.1 \%)$ are aware. This indicate that most of the academic librarians in ATBU library are unaware of the Makerspace technology. Result of data analysis in table 2 , of the research question 2 , indicate that $13(50 \%)$ of the respondents strongly agreed to the need for the adoption of Makerspace in the library while 12(46.15\%) agreed. However, 5(19.24\%) and 4(15.38\%) disagreed and strongly disagreed for the adoption of Makerspace. Their responds to disagreement may be connected with the huge amount of financial commitment in establishing the new technology in the library. Analysis in table 3 under research question number 3 , revealed the benefits that the librarians and other users as well as the library would derived in introducing Makerspce, $16(61.54 \%)$ of the respondents strongly agreed while 3(11.54\%) disagreed that introducing Makerspace in the library would have benefit to the librarians and other library users. However, there are some perceived challenges which are possible to be encountered in introducing Makerspace in the library such as the problem of staffing $12(46.15 \%)$ and the issue of maintenance of the equipments, $13(50 \%)$. Furthermore, $3(11.54 \%)$ of the respondents disagreed to the challenges that the library may encountered in introducing the new technology. The reasons for this argument may be related to the respondents' consideration of the benefits which the library would enjoy by introducing the new technology. Analysis of data in research question5, proffer solutions to the effective adoption of Makerspace in the library. Some respondents strongly agreed for provision of adequate funding to the library while others are of the view that adequate security measures should be provided in the library. Other respondents agreed that adequate power supply (14(53.85\%) should be the main consideration before adoption of a Makerspace.

\section{CONCLUSION AND RECOMMENDATION}

The paper examine Makerspace as emerging technology and innovation in academic libraries: a call for adoption in ATBU library. A total of 26 ATBU academic librarians participated in the study. Findings revealed that most of the academic librarians in ATBU are unaware of the emerging technology in libraries and also, 16(61.54\%) of the librarians agreed that adoption of the new technology would developed an entrepreneurial spirit among academic librarians and other library users. The paper further discovered that inadequate funding was the major constraint to effective adoption of Makerspace in the library. Suggestions were proffered in respect to the challenges to be encountered such as provision of adequate funding, training of academic librarians and adequate power supply in the library among others for successful adoption of the new technology. 
In line with the result of the study, the researchers proffer the following recommendations as follows:

$>$ Academic librarians should embrace the new emerging technology and participate fully through training on the new technology and bring about the development of Makerspace in their libraries. This will also go a long way in creating and sharing of new ideas among themselves.

$>$ They should call for adoption of the new emerging technology in their libraries so as to be part of the libraries that introduced Makerspace.

$>$ Academic libraries should create a space for the development of makerspace by decongesting some of the unwanted library resources in their libraries and also to co-exist and to collaborate with other learning spaces and operations such as workrooms and workstations.

$>$ The Library should provide adequate security measures to protect the new resources introduced in the library. In other to ensure adequate security of the new resources, libraries and mother institution should provide available funds to acquire security gadgets such as closed circuit television cameras (CCTV) and other security devices to curb or reduce the menace of theft or damage to the resources.

\section{REFERENCES}

[1]. American Society of Engineering Education (ASEE,2015). A review of university makerspaces. $122^{\text {nd }}$ ASEE Annual Conference and exposition.: Seattle, WA, June 14-17. https://smartech.gatech.edu/bitstream/handle/1853/53 813/a _ review _ of _ university_ maker_spaces.pdf Retrieved November 28, 2018.

[2]. Anderson, C. (2012). Makers: The new industrial revolution. New York: Crown Business.

[3]. Britton, L. (2012), "The makings of maker spaces, part 1: space for creation, not just consumption", Library Journal, available at: ww.thedigitalshift.com/2012/10/publicservices/ themakings-of-maker-spaces-part-1-space-for-creationnot-just-consumption/(accessed April 2, 2014).

[4]. Burke, J. (2014). Makerspaces: A practical guide for librarians. Lanham (MD). Rawman \& Littlefield.

[5]. Burke, J. (2017). Making sense: can makerspace work in academic libraries? www.ala.org/scr/files/content/conferences/confsandpr eeonfs/2015/Burke.pdf. Retrieved June 10, 2018.

[6]. Fatma, A.M. AL-Mousawi,(2018). Maker-space: The New Trend of Academic Library services. $24^{\text {th }}$ Annual conference and exhibition of the special libraries Association, Arabian Gulf, Muscat.

[7]. Ginsberg, S. (2016). Top 4 reasons why makerspaces matter in academic libraries and to get started. Retrieved from www.ideas .demo.com/blog/top-4reasons-why-maker-spaces-matter-in-academiclibraries/Retrieved February 10, 2019.

[8]. Matthews, G., \& Walton, G. (2014), "Strategic development of university library space:

[9]. Widening the influence" New Library World, Vol. 115 , No. (5/6), pp. 237-249.
[10]. Moorefield-Lang, H. M. (2015). User agreements and makerspaces: a content analysis. New Library World, 116(7368-358)8/.

[11]. Oduagwu, E.A. (2006). Libraries and information management in a globally networked society. Owerri: Tony Ben publishers.

[12]. Preddy, L.B. (2013), School Library Makerspaces: Grades 6-12, Libraries Unlimited, Santa Barbara, CA.

[13]. Radniecki, T. and Klenke, C. (2017). Academic library makerspaces: supporting new literacies and skills.www.ala.org/acr/site/ala.org.acr/files/content/co nfsandpreconfs/2017/Academiclibrarymakerspaces.pd f Retrieved September 14,2018.

[14]. Reitz, J.M. (2004). Dictionary of library and information science. Wesport, Connecticut: Libraries unlimited.

[15]. Slater, D and Howard, Z. (2013).A place to make, hark and learn: makerspaces in Australian public libraries.

http://dx.doi.org/10.1080/00049670.2013.853335

Retrieaved July 24, 2018.

[16]. Taylor, N., Hurley, U., and Connolly, p. (2016). Making community: the wider role of makerspaces in public life. In Proceedings of the $2016 \mathrm{CHI}$ Conference on Human Factors in Computing Systems. ACM, 1415-1425.

[17]. Turner, A., Welch, B. \& Reynolds, S. (2013). Learning spaces in academic libraries: A review of the evolving trends. Australian Academic and Research Libraries.44(4),226-234. Retrieved from http://dx.doi.org/10.1080/00048623.2013.857383. Retrieved August 15, 2018.

[18]. Weinman, J. (2014). Makerspaces in the university community. Master thesis. Institute of product development, Technologt Universitat Munchen. https://web.stanford.edu/group/desig education/wikiupload/0a/Weinmann_ masters_thesis.pdf Retrieaved August 17, 2018.

[19]. Wilczynski, V., and Adrezin, R. (2016). Higher Education Makerspaces and Engineering Education. In ASME 2016 International Mechanical Engineering Congress and Exposition (pp. V005T06A013V005T06A013). American Society of Mechanical Engineers.

[20]. Wong, A and Patrige, H. (2016). Making as learning: makerspaces in universities. Australian Academic and Research Libraries, 47(3), 143-159. Doi: 10.1080/00048623.2016.1228163. 